\title{
Summary of Age-Dating Analysis in the Fenner Basin, Eastern Mojave Desert, California
}

\author{
M.L. Davisson
}

\section{June 1, 2000}

U.S. Department of Energy

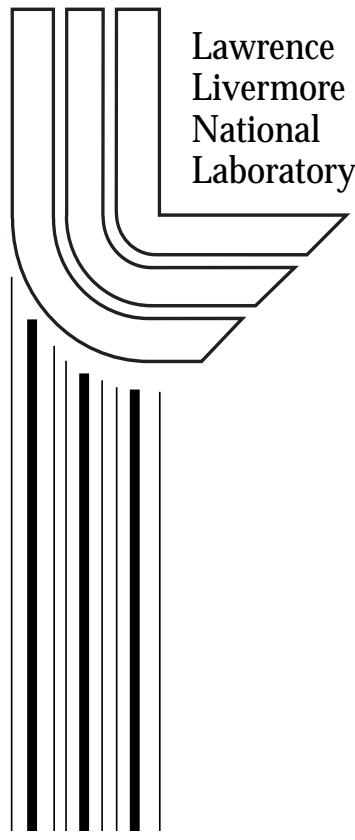




\section{DISCLAIMER}

This document was prepared as an account of work sponsored by an agency of the United States Government. Neither the United States Government nor the University of California nor any of their employees, makes any warranty, express or implied, or assumes any legal liability or responsibility for the accuracy, completeness, or usefulness of any information, apparatus, product, or process disclosed, or represents that its use would not infringe privately owned rights. Reference herein to any specific commercial product, process, or service by trade name, trademark, manufacturer, or otherwise, does not necessarily constitute or imply its endorsement, recommendation, or favoring by the United States Government or the University of California. The views and opinions of authors expressed herein do not necessarily state or reflect those of the United States Government or the University of California, and shall not be used for advertising or product endorsement purposes.

Work performed under the auspices of the U. S. Department of Energy by the University of California Lawrence Livermore National Laboratory under Contract W-7405-Eng-48.

This report has been reproduced directly from the best available copy.

Available to DOE and DOE contractors from the

Office of Scientific and Technical Information

P.O. Box 62, Oak Ridge, TN 37831

Prices available from (423) 576-8401

http://apollo.osti.gov/bridge/

Available to the public from the National Technical Information Service

U.S. Department of Commerce 5285 Port Royal Rd., Springfield, VA 22161 http://www.ntis.gov/

OR

Lawrence Livermore National Laboratory Technical Information Department's Digital Library http://www.llnl.gov/tid/Library.html 
Summary of Age-dating Analysis in the Fenner Basin, Eastern Mojave Desert, California

June, 2000

M. Lee Davisson

Health and Ecological Assessment Division 



\section{Age of Groundwater}

Stable isotopes of oxygen (oxygen-18) and hydrogen (deuterium) in water were measured to determine recharge sources for Fenner Basin groundwater. The deuterium and oxygen-18 signatures (reported as $\delta \mathrm{D}$ and $\delta^{18} \mathrm{O}$ values) ranged from -11.9 to -9.3 per mil (Davisson, 2000). The more negative values originate from high elevation recharge in the New York Mountains and were also observed in the northern and eastern parts of the groundwater basin. Less negative values were observed in the Providence Mountains along the western part of the basin. Groundwater collected in the Fenner Gap (i.e. Project Area) had signatures between -10.6 and -10.9 per mil, suggesting a mixture of recharge from both northern, western, and probably local recharge areas in the basin. The annual contribution of groundwater recharge to Fenner Gap from the Clipper, Marble, and Old Woman mountains is still inconclusive due to lack of isotopic data.

Isotopic signatures of mean annual precipitation collected by Friedman and others (1992) at Mitchell Caverns, as well as recently recharged groundwater in the Providence and New York mountains, are similar to the isotopic values in Fenner Gap groundwater. This indicates that this groundwater has a Holocene age (less than 10,000 years old), since groundwater recharged during the Pleistocene had isotopic signatures significantly more negative than today due to past global cooling (see Stute et al., 1995; Guilderson et al., 1994).

Shallow groundwater in recharge areas of the Providence and New York mountains were found to have groundwater less than 40 years old. This was concluded based on tritium and radiocarbon measurements, which were abnormally high in the groundwater. Tritium and radiocarbon are also abnormally high in the atmosphere due to surface testing of nuclear weapons in the early 1960s. Abnormal concentrations in the groundwater are consistent with young recharge.

Two independent and direct measures of groundwater age indicate groundwater in the Fenner Gap is around 1000 to 3000 years old. One approach measured the radiocarbon age of dissolved organic carbon (DOC) in a production (PW-1) in the Fenner Gap. The DOC originated from the soil of the recharge area(s) and flowed with the groundwater, largely unaffected by reactions with other carbon sources (Wassenaar et al., 1991). Preliminary measurements indicate the radiocarbon age of the DOC is between 1000 and 2800 years, with an estimate mean of 1500 years.

Another approach measured the accumulated helium-4 isotope dissolved in the groundwater also collected from the same production well in Fenner Gap at the same time as the radiocarbon sample. Continental crust rocks beneath groundwater basins produce helium-4 from radioactive decay of uranium and thorium. This helium-4 diffuses slowly upward toward the surface under steady-state conditions. Shallow groundwater above the crust will accumulate the helium- 4 in a dissolved state over time. The older the groundwater, the more helium-4 that accumulates. The helium-4 concentration measured on the Fenner Gap well indicates that the accumulated helium4 is only about 2 times above the concentration expected for water in equilibrium with air. This suggests the age is only between 1000 and 2000 years old. Ten-thousand year old water has accumulated helium- 4 concentrations approximately 10 times the concentration expected for water in equilibrium with the atmosphere (see Mazor and Bosch, 1992, Solomon et al., 1999).

The radiocarbon was also measured on the dissolved inorganic carbon (DIC) from groundwater in the Fenner Gap. Possible ages estimated from the DIC radiocarbon measurements range from less than 1000 up to 9000 years old. The wide range is due to uncertainty in subsurface geochemical reactions occurring between DIC and radiocarbon-absent limestone aquifer rocks. The geochemical pathways are poorly understood and cannot be predict based on available data (see Davisson et al., 1999; Davisson, 2000). 


\section{Acknowledgments}

This work was performed under the auspices of the U.S. Department of Energy by the University

of California, Lawrence Livermore National Laboratory under contract No. W-7405-Eng-48.

\section{References}

Davisson, M.L. Smith, D.K., Kenneally, J., Rose, T.P., 1999, Isotope hydrology of southern Nevada groundwater: stable isotopes and radiocarbon. Water Resources Research, 35, 279-294.

Davisson, M.L., 2000, Discussion regarding sources and ages of groundwater in southeastern California. Lawrence Livermore National Laboratory UCRL-ID-138321, 10 pp.

Guilderson, T.P., Fairbanks, R.G., Rubenstone, J.L., 1994, Tropical temperature variations since 20,000 years ago: modulating interhemispheric climate change. Science, 263, 663-665.

Mazor, E. and Bosch, A., 1992, Helium as a semi quantitative tool for groundwater dating in the range of $10^{4}-10^{8}$ years. In Isotopes of Noble Gases as Tracers in Environmental Studies. International Atomic Energy Agency Proceedings, Vienna Austria, 1989, pp. 163-178

Solomon, D.K., Hunt, A., Poreda, R.J., 1996, Source of radiogenic helium 4 in shallow aquifers: implications for dating young groundwater. Water Resources Research, 32, 1805-1813.

Stute, M., Forster. M., Frischkorn. H., Serejo, A., and others, 1995, Cooling of tropical Brazil (5Degrees-C) during the last glacial maximum. Science, 269, 379-383.

Wassenaar, L., Aravena, R., Hendry, J., Fritz, P., 1991, Radiocarbon in dissolved organic carbon, a possible groundwater dating method: case studies from western Canada. Water Resources Research, 27, 1975-1986. 